\title{
DETERMINING CUSTOMER SATISFACTION IN THE REAL ESTATE MANAGEMENT SECTOR IN RIGA
}

\author{
Iveta PUKīTE' 1 , Sanda GEIPELE ${ }^{2}$ \\ ${ }^{1,2}$ Riga Technical University, Latvia \\ Corresponding author e-mail: iveta.pukite@rtu.lv
}

\begin{abstract}
This article discusses the need to determine customer satisfaction and how to use it in non-mortgage asset management companies. The aim of the article is to discover the essential elements necessary for ensuring customer satisfaction in real estate management companies. A customer satisfaction survey, which enables the management company to gain information about customer needs and control the quality of provided services, is essential for successful operation of the companies in order to maintain a high standard in one of the fundamental values - quality of customer service.

The present article analyses the results of the research obtained by interviewing the clients of the real estate management company. In the conclusion, proposals are made for methods in order to continue improving customer satisfaction.
\end{abstract}

Keywords: Customer satisfaction, real estate management company, residential houses, valuation methods.

\section{INTRODUCTION}

One of the main aims of each company's development is to promote cooperation with its clients. This development goal recognises the importance of the client and professional staff in each company's operation and development, including the provision of uniform, high-quality customer service standards, forms, and types.

Customer satisfaction is increasingly seen as a decisive factor in ensuring a company's economic success. Already in the 20th century, empirical studies and scientific discussions from the world's most advanced countries led to a conclusion that a higher level of customer satisfaction encouraged customer attraction, strengthened their loyalty to specific companies, products, or brands, provided higher returns, created less need for product upgrades, and ensured lower price flexibility (Medne, 2007).

The aim of the paper is to find out the essential elements of customer satisfaction assessment, their necessity and impact on future operations for real estate companies, as well as to assess customer satisfaction in a company that provides residential houses in the city of Riga.

To achieve the aim, the following tasks have been set: to study the theory of customer satisfaction assessment; to conduct a survey of the company's clients in order to become aware of the quality of the services provided (according to the clients' evaluation); to evaluate customer satisfaction, identify problematic issues, and submit proposals for the service quality assessment. 
In the course of research, quantitative research methods and direct interviews have been used. The survey has identified various customer service related issues based on the opinions of the tenants in several Latvian municipalities. Clients (tenants) have been interviewed remotely (using distributed questionnaires). During the direct interview, two interview types have been conducted: one interview - with the employees of the company management and the other - with the executive staff in order to determine the impact of customer opinion on the company reputation.

\section{ASSESSMENT OF CUSTOMER SATISFACTION AND IMPACT ON COMPANY REPUTATION AND FUTURE PERFORMANCE}

The definition of a customer encompasses various meanings. A customer defined as a consumer, buyer and recipient of the service may be both natural and legal entity. Customers define quality, but employees of service providers deliver it. Consequently, a company executive who is willing to provide a quality service should consider a customer to be the central element of his/her activity (Eglìte, E., Eglīte, G., \& Grauduma, 2008).

The awareness of the customer opinion and attitude is a continuous process - in today's changing world, the demands of society are growing day by day and the achievements of yesterday are already considered a norm today. Real estate management companies should also be able to provide their customers with highquality services in order to make contract fulfilment as convenient, easy and enjoyable as possible.

Quality Expert Peter R. Scholtes (states, "only when you understand what your business processes and customers are, you will be able to assess the quality. If customers are people who receive the services you provide, they can then determine "what" the quality is, just they can tell you "what" they want to receive and "what" they want it. For this very reason, many quality management experts say that quality starts with the client." (Scholtes, 1992)

Determining customer satisfaction in service companies, especially in the real estate management sector, is becoming increasingly important in the work of customer service specialists of these companies. The quality, honesty and customer satisfaction of real estate management companies are increasingly being discussed in the public environment, which affects the reputation of the company as a whole.

This is mainly determined by the specifics of the service provided in the field of real estate management. The level of satisfaction in this sector is mainly associated with the quality and price of the service provided, mode of communication and deadlines. Satisfaction with the services used in this process may even play a decisive role. It can lead to positive feedback on the company, which results in attraction of new clients or to a completely opposite result, i.e., clients can relinquish the services of the company. In its turn, the use of positive feedback ensures that the company is recommended to potential customers.

The real estate management sector is also characterised by the fact that in most cases there is not one but several clients in the managed property - they can be apartment owners, leaseholders, tenants or owners of villages of single-family homes. Consequently, a situation can arise in which customer satisfaction or 
dissatisfaction can lead to the risk of dispersal of customers and the formation of opposition.

Customer satisfaction pays off as a satisfied customer will continue using the services of the company associated with best experience and will recommend this company to others. Customers who have little satisfaction with the management services received will start increasingly express their dissatisfaction over time involving other owners, leaseholders, or tenants. As a result, if the company ignores this process, there is a risk that the client will make a decision to terminate the contract with the existing management company and conclude the agreement with another company that is more loyal to its customers. Losing customers, the company experiences losses:

1) potential revenue from the services provided to clients is not obtained;

2) negative impact on reputation;

3) pressure from the senior management on the personnel due to unprofessional conduct.

Company executives or owners often ask a question, "What is the precentage of our customers who are satisfied with the services we provide? What is the precentage of our customers who are absolutely loyal to our company and create positive word-of-mouth about our company?" Company executives are aware that high customer satisfaction is one of the keys to the company's future success and that customer satisfaction guarantees a qualitative and quantitative increase in the market share and a steady flow of cash in the future. Figure 1 demonstrates customer response in case of satisfaction or dissatisfaction.

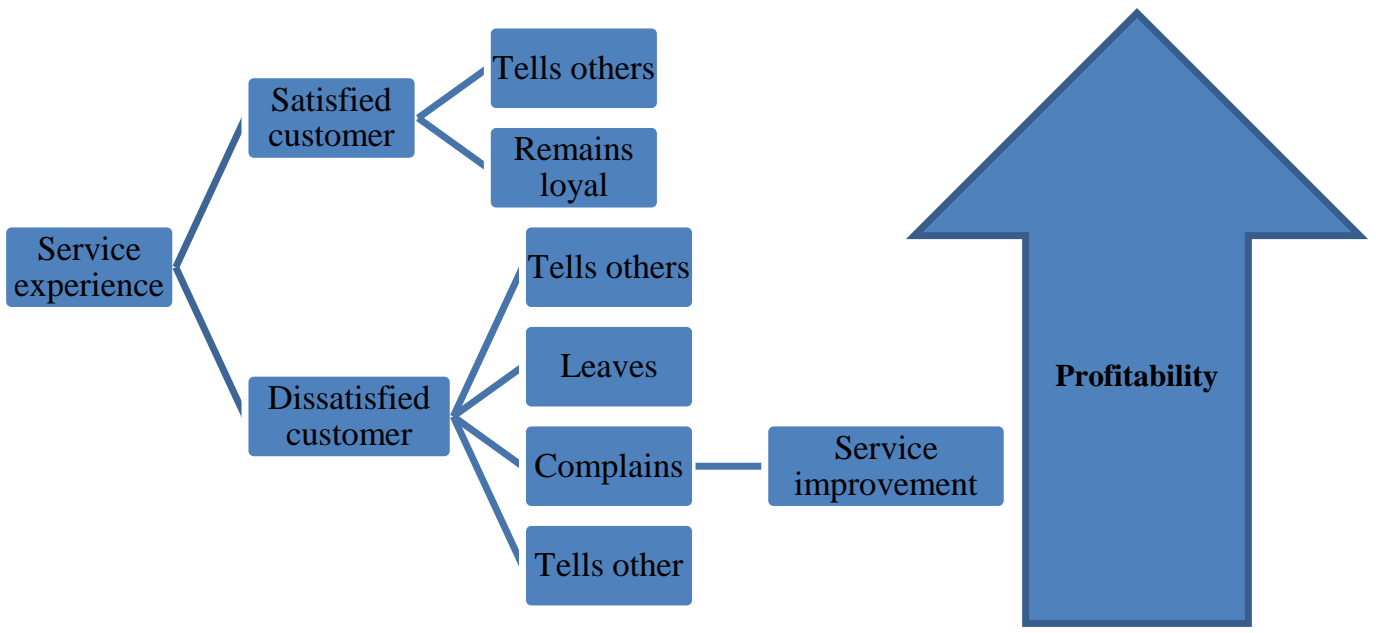

Fig. 1. Customer's response in case of satisfaction or dissatisfaction

(Leiks \& Hekī, 2005, p. 86).

The authors of the article have added customer response in the event of dissatisfaction to Fig. 1, i.e., when the customer is dissatisfied, he/she also complains and tells one's colleagues, friends, family members, etc. about the problem. In recent years, it has become increasingly popular among dissatisfied clients, who are unable to resolve the conflict in their desired direction, to draw attention to their problems in the public domain through television. In this case, it 
can have an adverse effect on the reputation of the company because bad news in the public environment is spreading fast.

One of the solutions to find out customer satisfaction is to conduct a satisfaction survey. There are different methods how to accomplish it.

Research methods can be divided into subjective and objective methods:

1) objective methods are based on various objectively fixed criteria: turnover, market share, profit measurements, customer churn and retention indictors. However, exactly these, i.e., objective methods, are in fact considered to be most unreliable, as they are influenced by a number of other factors that are not related to customer satisfaction;

2) subjective methods are mainly based on the individual, subjectively perceptible factors of customer satisfaction, such as complaints expressed, opinion with respect to the expected services. The range of these methods is quite extensive, so they can be further subdivided. They can be:

a) service-oriented evaluation: analysis of complaints, clarification of necessary additional services, surveys, measurement with satisfaction scales;

b) event-oriented: observation, sequential event method, problem frequency/relevance analysis, etc. (Beutin, 2003, p. 118).

Customer satisfaction survey helps provide products and services that are tailored to customer preferences. Attracting a new customer to a company usually costs more than keeping an existing one; therefore, many companies are interested in reducing the trend when customers try the product, but do not continue buying it.

Competitive power of a real estate management company is largely defined by the degree of its conformance to customer needs. In the information age, organisations require new capabilities for competitive success, such as customer relationships, product innovation, customised products, employee skills, motivation, and information technology (Titko \& Lāce, 2010).

The introduction of customer satisfaction survey, which can provide an opportunity to obtain information about the needs of customers and control the quality of services provided, is essential for the successful operation of the company in order to maintain one of the core values - customer service quality - at a high level (Putniņš, 2007).

One of the most popular and easiest methods to measure customer satisfaction with the services provided by the company is to conduct customer surveys.

The identification of customer satisfaction through a survey represents a second group of subjective methods of customer satisfaction - service-oriented methods. Using this method, it is possible to get an overview of the state of the company services, using a variety of scales, as a large number of business customers are usually interviewed (Medne, 2007).

Identification of the customer value scale is an important aspect of customer satisfaction survey in order to objectively interpret the obtained results and determine the proper strategies for customer satisfaction management after determining the level of satisfaction, as different elements of the service, for example, quality of service, price, personnel competence, etc., can vary in meaning or value according to customer perception. In the customer satisfaction assessment, 
companies should not be limited to the use of one method; they should use several methods, adjusting each method to a certain satisfaction dimension (Medne, 2007).

As consumer loyalty plays an integral role in business success in competitive markets (Kotler \& Armstrong, 2010; Oliver, 1999; Demirci Orel \& Kara, 2014), numerous studies have examined various factors that motivate consumers to remain loyal to a company's products and services. However, little emphasis has been placed on the effect of Corporate Social Responsibility (CSR) on attracting loyal consumers and increasing their number (Liu, Guo, \& Lee, 2011). CSR typically consists of legal, ethical, and philanthropic responsibilities that represent the company's concern for society (Stanaland, Lwin, \& Murphy, 2011), which also functions as a self-regulatory mechanism that monitors whether the company complies with these responsibilities (Park, Kim, \& Kwon, 2017).

Conducting satisfaction surveys, it is important to choose proper questions for the survey. It is also important to know which customers, when and how often to ask these questions. However, the most important issue is to understand how to analyse the answers received so that they can be applied to promote company development and help achieve business goals. The satisfaction survey aims at analysing whether customers receive exactly what they want from the company.

For such an analysis, it is essential to define the most important criteria for a product or service by considering customer preferences and satisfaction level regarding these criteria (see Fig. 2):

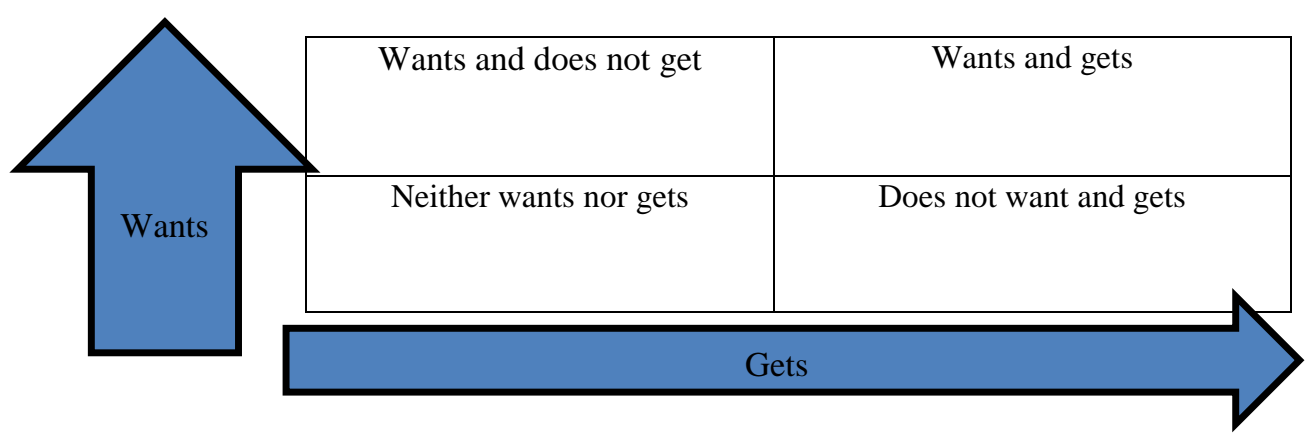

Fig. 2. Analysis of customer satisfaction (Soliddata, 2017).

The best place for the product and service criteria is the position "wants and gets" demonstrated in Fig. 2, as these criteria are most desirable to customers and they also provide the highest level of satisfaction. Criteria that are in the position "neither wants nor gets" are also beneficial for a company as customers give little importance and the company spends little resources on ensuring these criteria. The worst position for the product and service criteria is if customers want products or services, but are dissatisfied with the level of quality provided by the company the position in Fig. 2 - "wants and does not get". The company should devote more resources to increase customer satisfaction with these criteria. Resources can be considered unnecessarily spent if the product criterion is not important for customers, but the company spends a lot of resources to maintain it (Soliddata, 2017). 
Customer satisfaction assessment is closely related to Corporate Social Responsibility. It is always a planned and purpose-driven set of activities to bring more benefits to business and society as a whole. Corporate Social Responsibility plays an important role in the management and administration of real estate.

Values are considered to be the company's cultural code. This is an intangible and directly invisible part of a company that cannot be touched and evaluated, which is why company executives often ignore this significant value. However, studies (Ackoff, 1994) show that a clear system of company values has been one of the indicators, which has contributed to long-lasting performance and high financial results (Dāvidsone, 2008).

When a company's product or service matches an individual's personal values, that person is likely to evaluate the company more positively. Applying the concept of human values to the CSR context, prior studies have found that consumer awareness and evaluations of CSR actions are mainly determined by their own values (Basil \& Weber, 2006; Golob, Lah, \& Jančič, 2008; Wang \& Juslin, 2012). Thus, it is plausible that consumer perception of a company's CSR quality and commitment is positively influenced when the consumers' personal values are congruent with the company's CSR goals or activities (Park et al., 2017).

Corporate Social Responsibility can be a modern tool to attract stakeholder attention and improve one's own image by gaining loyal customers and loyal partners.

\section{CASE STUDY AT A MUNICIPAL ENTERPRISE: MANAGING RENTAL HOUSING IN THE MUNICIPAL PROPERTY}

\section{The aim of the customer satisfaction survey is:}

To evaluate customer satisfaction by identifying problematic issues and performing customer satisfaction analysis and to formulate proposals for improving service quality in cooperation with customers to increase customer satisfaction.

The survey was conducted in October and November 2016. The main task of customer satisfaction survey was to determine overall customer satisfaction with the company services. Data input: A total of 1023 questionnaires were processed. Overall satisfaction (see Fig. 3) was evaluated according to a 10-point grading system.

On the basis of the responses received, it can be concluded that municipal waste collection and street cleaning services are particularly highly evaluated. In general, overall satisfaction with the company operation in house management is 7.6 points, which is a good indicator. 


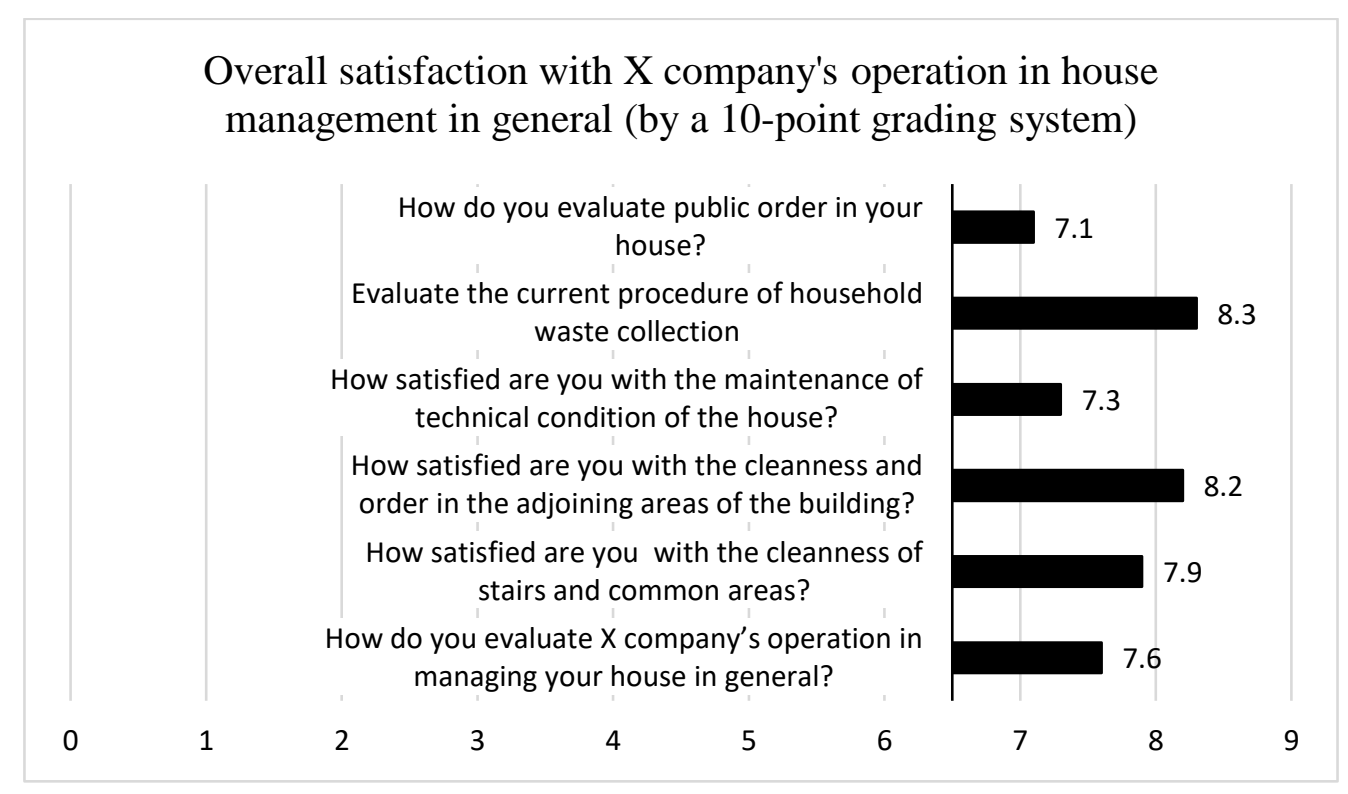

Fig. 3. Overall satisfaction with the company operation in house management.

As shown in Fig. 3, technical maintenance works in the building are poorly rated, which indicates that customers are willing that the quality of maintenance (construction) of building is improved. Therefore, the company would need to establish a high-quality technical support office, as well as to conclude outsourcing contracts with construction companies for works that cannot be carried out by the employees of the company, which would provide the basis for improving the assessment of the technical maintenance of the building.

Most common complaints about technical maintenance works are:

1) cosmetic repair of the staircase is not performed;

2) the facade is not repainted;

3) defects in the interior doors of the staircase;

4) there is no electronic door lock.

The next step is to identify how tenants pay for the services received (see Fig. 4). From the responses given, it is evident that most payments are made through online banking systems, but paying at the supermarkets is the least popular way. This shows that the company customers follow the developments of information technology or they use their relatives' assistance. 


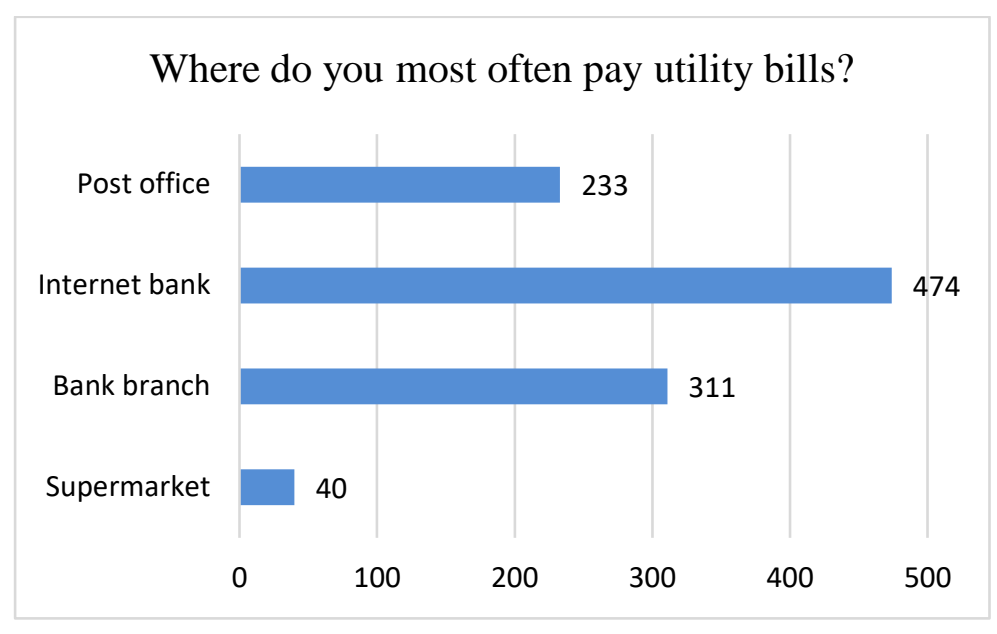

Fig. 4. Where do you most often pay utility bills?

Consequently, the issue of paying bills on the company website has also become topical for the company. Therefore, the following question was asked "Would you take an opportunity to view and pay utility bills on the company website?" (see Fig. 5).

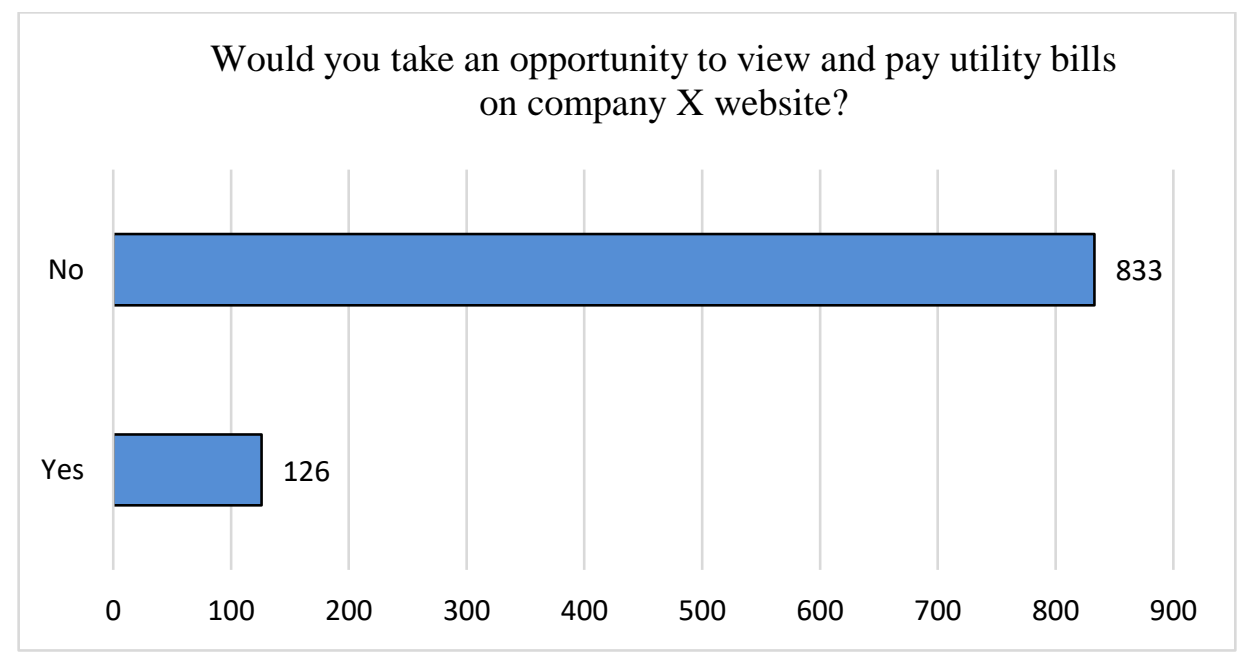

Fig. 5. The desire of the tenants of the company to take an opportunity to view and pay utility bills on the company website.

Unfortunately, survey data indicate that most of the respondents are not ready to use the company website to receive information about their bills, as well as to pay them. The implementation of e-environment would enable the company to improve the circulation of information, communicate with the client through Internet services, reduce the working hours of employees who work with tenants on a daily basis and carry out explanatory work. The use of such a service would also reduce the risk that a tenant has not received his/her bill in the paper form, as it can always be viewed on the company website using his/her personal passwords. 
In order to find out general information related to communication and deadlines, the following questions have been formulated:

1) satisfaction with the culture of work performance;

2) satisfaction with the information provided at the office;

3) due-date satisfaction;

4) satisfaction with service prices.

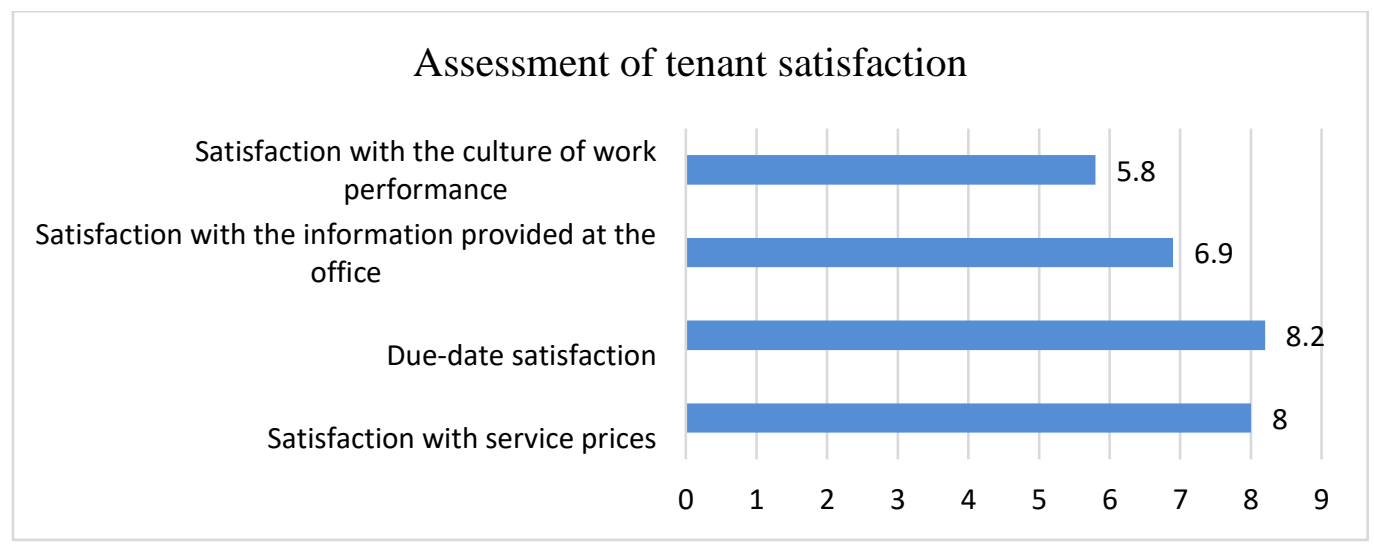

Fig. 6. Assessment of tenant satisfaction based on a general service.

Data show that communication and the culture of work performance are highly rated. However, satisfaction with service prices and deadlines has received a lower rating.

The authors conclude that, according to the Pareto principle, these two causes lead to $80 \%$ of customer complaints. Thus, the customer needs in the company are as follows: strict observance of deadlines and economically reasonable pricing for the provided services.

In general, surveys of this kind require the company to analyse respondents' responses and evaluate the measures to be taken to improve the overall performance of the company, efficiency, quality and customer satisfaction. It is therefore essential for the company to set its own values, which act as an indicator for assessing the company results and foreseeing future prospects.

During the research, employees of the company who provide services to the tenants have been interviewed. The interviews have resulted in the following main findings:

1) identification of the level of customer satisfaction provides an opportunity for a company to evaluate its operating principles and engage in further implementation of its strategy;

2) identifying the main causes of dissatisfaction, it is necessary to develop an action plan to address the problems found out during the customer satisfaction survey. The elaboration of an action plan initially reveals a shortcoming and then proposes the prevention measure to eliminate the shortcoming;

3) customer questionnaires are worthless if they are not analysed and no tasks are set in order to solve problems in the future; 
4) if there are conflicts between tenants and the management company, the most common tenants' behaviour is to complain to their municipality, write complaints on the Internet, or use television, where only one view of the problem is usually presented. The situation as a whole is not analysed. However, whether or not a party is right, any complaint of this kind, which goes public, has a significant impact on the business as a whole. This may lead to the risk that tenants are more likely to influence each other and, as a result, general dissatisfaction may appear;

5) taking into account that the company has well-defined values and their implementation mechanism, the management should ensure that they are implemented in practice;

6) real estate companies, especially those operating in the rental market, could increasingly focus on the introduction of Corporate Social Responsibility in their operations in the future as housing affects a large part of the population of the country, who, for various reasons, use the services of the rental market.

Values are objects that provide persuasive assurance of the priority action or goal compared to another goal or mode of action. The company's core values as essential and durable business principles of the company. Values provide answers to two important questions: what is good (as opposed to what is bad) and what is right (as opposed to what is wrong). There is no such thing as reality; everything is determined by the prism of perception through which one looks at the world. Values make up the ethical perception prism. What is right and correct, therefore, is in line with the value system of the company, it is supported by the company, which is not - condemned and should be discarded (Dāvidsone, 2008).

Corporate Social Responsibility in a real estate management company should be planned and targeted as a set of activities in order to provide greater benefits to the business and society as a whole; therefore, CSR plays an important role in the management and administration of real estate.

\section{CONCLUSION}

In order to achieve a high level of productivity, increased work efficiency, improved work processes, quality and customer satisfaction, an enterprise needs to develop internal processes that clearly indicate the actions that each employee should take, and a plan for the interaction of all parties involved in the overall process.

The company should specifically explore the possible sources of positive assessments provided by satisfied customers in order to apply these findings to other situations and thus improve the level of overall satisfaction, i.e., to find out what makes tenants satisfied and apply this elsewhere.

Assessment of customer satisfaction and further integration of customer needs and wishes into the company operations is a component of Corporate Social Responsibility, which, in turn, is already geared toward the development and sustainability of future mutual benefits. 
Tenant satisfaction is a subjective assessment made by a consumer and based on the use of the services in his/her environment.

The tenant's behaviour in the real estate market is a process divided into five stages (problem identification, search for information, evaluation of alternatives, receipt of the service, and behaviour within the lease period).

There is no uniform customer behavioural model, but all is based on the consumer's needs and wants, which are influenced by the external and internal environment, and which also define the essential characteristics of the customer's needs.

Ultimately, customer satisfaction can be created only by a combination of all of the accommodating factors, which means that the service must be high-quality, professional, cost-effective, and environmentally attractive to the client, as well as to the real estate management service.

Customer satisfaction can be assessed by various methods that can be subjective and objective. In practice, subjective methods are used more often, since they can reflect customer satisfaction more accurately, but the number of subjective impressions must be sufficiently large in order to provide the correct premise regarding the information that has been gathered.

Despite the fact that opinion obtained through personal experience is considered to be more valuable, the media also has a strong, increasing influence on the formation of attitudes and opinions in the society.

\section{REFERENCES}

Ackoff, R. L. (1994). Systems thinking and thinking systems. System Dynamics Review, 10(2-3), 175-188. https://doi.org/10.1002/sdr.4260100206

Basil, D. Z., \& Weber, D. (2006). Values motivation and concern for appearances: the effect of personality traits on responses to corporate social responsibility. International Journal of Nonprofit and Voluntary Sector Marketing, 11(1), 61-72. https://doi.org/10.1002/nvsm.38

Beutin, N. (2003). Verfahren zur Messung der Kundenzufriedenheit im Überblick. Kundenzufriedenheit, $115-151$.

Dāvidsone, G. (2008). Organizāciju efektivitātes modelis [Organization Performance Model]. Rīga: Organization Development Academy.

Demirci Orel, F., \& Kara, A. (2014). Supermarket self-checkout service quality, customer satisfaction, and loyalty: Empirical evidence from an emerging market. Journal of Retailing and Consumer Services, 21(2), 118-129. https://doi.org/10.1016/j.jretconser.2013.07.002

Eglīte, E., Eglīte, G., \& Grauduma, I. (2008). The Role of Customer in Evaluation of the Quality in Higher Education. Quality and Relyability, 29, 24-33. ISSN 1407-8015.

Golob, U., Lah, M., \& Jančič, Z. (2008). Value orientations and consumer expectations of Corporate Social Responsibility. Journal of Marketing Communications, 14(2), 83-96. https://doi.org/10.1080/13527260701856525

Kotler, P., \& Armstrong, G. (2010). Principles of marketing. New Jersey, NJ: Pearson education. ISBN 100137006691

Leiks, N., \& Hekī, K. (2005). Klientu apkalpošana [Customer Service]. Rīga: Lietišķās informācijas dienests.

Liu, C.-T., Guo, Y. M., \& Lee, C.-H. (2011). The Effects of Relationship Quality and Switching Barriers on Customer Loyalty. International Journal of Information Management, 31(1), 71-79. https://doi.org/10.1016/j.ijinfomgt.2010.05.008

Medne, I. (2007). Klientu apmierinātības novērtēšanas metožu attīstība un lietošanas iespējas tūrisma uzṇēmumos [Development and Application Possibilities of Evaluation Methods of Customer Satisfaction in Tourism Enterprises]. Management, 117, 394-407. 
Oliver, R. L. (1999). Whence Consumer Loyalty? Journal of Marketing, 63, 33-44. https://doi.org/10.2307/1252099

Park, E., Kim, K. J., \& Kwon, S. J. (2017). Corporate Social Responsibility as a Determinant of Consumer Loyalty: An Examination of Ethical Standard, Satisfaction, and Trust. Journal of Business Research, 76, 8-13. https://doi.org/10.1016/j.jbusres.2017.02.017

Putniņš, A. (2007). Organizācijas dzīves cikls un organizācijas kultūra [Organizational Life Cycle and Organizational]. Management, 117, 218-226.

Scholtes, P. R. (1992). The Team Handbook. Madison, WI: Joiner Associates.

Soliddata. (2017). Klientu apmierinātības pētījumi [Customer Satisfaction Surveys]. Retrieved from http://www.soliddata.lv/company/news/klientu-apmierinatibas-petijumi/. Review 01.09.2017.

Titko, J., \& Lāce, N. (2010). Customer Satisfaction and Loyalty in Latvian Retail Banking. In: International Scientific Conference "Economics and Management 2010": Programme and Collected Abstracts (pp. 85-86), Latvia, Riga, 22-23 April, 2010. Riga: RTU Press. ISBN 9789934100185

Wang, L., \& Juslin, H. (2012). Values and Corporate Social Responsibility Perceptions of Chinese University Students. Journal of Academic Ethics, 10(1), 57-82. https://doi.org/10.1007/s10805-012-9148-5

\section{AUTHORS' SHORT BIOGRAPHIES}

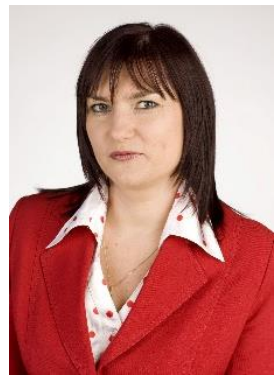

Iveta Puk̦ite, Mg. sc. ing., a Researcher of the Faculty of Engineering Economics and Management at Riga Technical University (RTU) and a PhD student at RTU. She received the Master's degree in management sciences from the University of Latvia. She is a Lecturer at the College of Law and the Head of Real Estate Management Department at “Ādažu Namsaimnieks" Ltd. I. Puķīte has participated in the international scientific conference "Economic Science for Rural development", Jelgava, Latvia, in the 3rd European interdisciplinary forum "Drivers for Progress in the Global Society", Vilnius, Lithuania, and others. Her research area is the socially responsible housing lifecycle of the management system.

ORCID iD: http://orcid.org/0000-0003-2500-0501

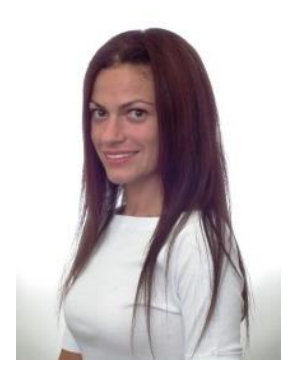

Sanda Geipele, Dr. oec., Assoc. Prof., Riga Technical University, Latvia. She is an Expert in Management and Economic Sciences of the Latvian Council of Science. Her work experience has been acquired both in the private sector and in public administration, including real estate tax administration for several years at Riga City Council's Municipal Revenue Department. Her research interests are in the areas of sustainability development problems of real estate market, household resource management, construction industry, including land use management and institutional economics. She is the author and a co-author of more than 60 scientific publications, including the scientific monograph "Management System of Real Estate Market Development in Latvia" (2015) and two monographs with co-authors "Models of Financing Housing Fund Renovation in Latvia" (2012) and "Socio-Economic Aspects of the Interaction of Urban and Regional Development” (2012). 